\section{The side-effects of different doses of iron sulfate on women of reproductive age: a randomized double-blind, placebo- controlled study}

\section{Efeitos colaterais do sulfato ferroso administrado em diferentes posologias em mulheres em idade reprodutiva: estudo randomizado, duplo cego e controlado por placebo}

Katia Maria de Melo Machado 1

Luiz Oscar Cardoso Ferreira 2

Ariani Impieri de Souza 3

Alcides da Silva Diniz 4

1,2 Departamento de Medicina Social. Faculdade de Ciências Médicas. Universidade de Pernambuco. Rua Arnóbio Marques, 310. Sto. Amaro. Campus Universitário. CEP 50.100-130. Recife, PE, Brasil. E-mail: kmmmachado@hotmail.com

${ }^{3}$ Instituto de Medicina Integral Prof. Fernando Figueira. Recife, PE, Brasil.

4 Departamento de Nutrição. Centro de Ciências da Saúde. Universidade Federal de Pernambuco. Recife, PE, Brasil.

\begin{abstract}
Objectives:to identify side effects of the use of different doses of iron sulfate (IS).

Methods: an eight-week randomized, double blind, placebo-controlled trial was carried out involving 727 women aged 20-49 years between October 2005 and October 2006. The women were randomly allocated into eight groups with daily or twice-weekly doses administered during or in between meals. The information was obtained by weekly telephone contact. Analysis involved comparison of the proportion of complaints from the different groups.

Results: of 726 women initially selected, $74.2 \%$ completed eight weeks of follow up. In the regimens containing IS $95.2 \%$ of women reported gastrointestinal complaints. More complaints were reported for daily doses than for ones $(p<0.001)$. Those taken between meals were associated with more nausea than those taken during meals $(p<0.001)$. Of the 95 women who withdrew from the experiment, $88.4 \%$ belonged to the IS group and diarrhea was the main complaint (29.8\%).

Conclusions: the use of iron sulfate was associated with gastrointestinal side effects, especially when taken daily and diarrhea was the main complaint associated with IS.
\end{abstract}

Key words Iron sulfate, Women's health, Anemia iron-deficiency, Iron

\section{Resumo}

Objetivos: identificar efeitos colaterais com o uso do sulfato ferroso (SF) administrado em diferentes posologias.

Métodos: realizou-se ensaio randomizado, duplo cego, controlado por placebo, com duração de oito semanas, em 727 mulheres de 20-49 anos, entre outubro/2005 e outubro/2006, alocadas aleatoriamente em oito grupos de estudo, segundo o uso do SF ou placebo, frequência de utilização (diária ou duas vezes por semana) e horário de administração - durante (DR) ou no intervalo (IR) das refeições. As informações foram obtidas através de contato telefônico semanal. A análise foi feita por meio da comparação das proporções das queixas relacionadas aos diferentes esquemas posológicos.

Resultados: das 727 mulheres inicialmente selecionadas, 74,2\% completaram as oito semanas de seguimento. Os esquemas posológicos contendo SF foram responsáveis por $95,2 \%$ das queixas gastrointestinais. Tais queixas estiveram ainda relacionadas aos esquemas posológicos diários quando comparados aos esquemas semanais $(p<0,001)$. As tomadas no IR estiveram mais associadas à náusea do que as tomadas $D R(p<0,001)$. Das 95 mulheres que abandonaram o experimento, $88,4 \%$ pertenciam aos grupos do SF e, entre estas, a diarréia foi o principal motivo (29,8\%) alegado.

Conclusões: o uso do sulfato ferroso esteve associado a efeitos colaterais gastrointestinais. A diarréia foi a queixa mais associada ao uso do $S F$ e principalmente nos esquemas posológicos de tomada diária.

Palavras-chave Sulfato ferroso, Saúde da mulher, Anemia ferropriva, Ferro 


\section{Introduction}

The improvement of diet, combating intestinal parasites, enriching foodstuffs and taking iron salts in different doses have been some of strategies that have been used since the 1950s to combat iron-deficiency anemia. ${ }^{1}$ Although these measures are theoretically well-established, they have not been shown to be effective in solving the problem and it is still highly prevalent, especially in developing countries, such as Brazil, and among children and women of child-bearing age.2-6 There is, therefore, still no consensus regarding the best strategy to deal with this. ${ }^{7}$

Issues relating to the bioavailability of iron in food, diets rich in substances that hinder its uptake, problems with absorption and low adherence to treatment have been suggested as factors that reduce the efficacy of large-scale anemia prevention and treatment programs. $7-9$

There are many different compounds containing iron, all of which aim to improve the efficacy, tolerance and adherence to use. However, iron sulfate (IS), is still the drug of choice for the treatment of iron-deficiency anemia, since it is effective, low cost, and easily absorbed, compared with other iron salts. 10,11 Its effectiveness in correcting anemia and re-establishing iron deposits is the same as other compounds, but the gastro-intestinal intolerance that it may provoke, has limited this. 12,13 More modern iron compounds, such as iron chelate, despite being more effective and less associated with sideeffects, 14 are expensive and cannot therefore be widely used in public health. 1,2

The side effects of the use of iron salts have led to a tendency to use progressively smaller doses of this mineral, in an effort to reduce the incidence of undesirable gastrointestinal effects, such as a metallic taste in the mouth, nausea, heart-burn, abdominal pain, diarrhea or constipation. 10,13

Alternatives that minimize the undesirable effects of iron salts include the use of new regimens, such as a reduction in the dosage or in the frequency of doses. 13 These new proposals have improved treatment by reducing the blocking of iron absorption caused by habitual doses considered to be "high" and have, on the other hand, increased adherence by reducing side-effects. ${ }^{14,15}$

The aim of the present study is thus to investigate the side-effects of IS treatment in different doses and the reasons for abandoning treatment of women of reproductive age who use the health services in the Brazilian city of Recife.

\section{Methods}

A randomized, double-blind placebo-controlled field trial was conducted with women attending the Centro Integrado de Saúde Amaury de Medeiros (CISAM) which is part of the Universidade de Pernambuco (UPE) between October 2005 and October 2006.

The study covered 727 non-pregnant women aged between 20 and 49 years, resident in the Metropolitan Region of Recife, who had a telephone for subsequent weekly contacts. In order to ensure that the study was double-blind, only the researcher responsible for recruiting the women was aware of the type of treatment given, while the telephone interviewer and the woman herself were not aware of which kind of medication was provided. Women were excluded from the study if they had gastrointestinal disorders, had hemoglobin levels $\geq 15 \mathrm{~g} / \mathrm{dL}$ (when allocated to the IS groups) or when they had hemoglobin levels $\leq 11 \mathrm{~g} / \mathrm{dL}$ (when allocated to the placebo group).

The sample size of 80 women per group was calculated using the equation based on the difference of proportion. 16 Adherence to the weekly use group was considered to be $90 \%$ and $70 \%$ for the daily use group and the probability of Type I error was taken to be 0.05 and the probability of Type II error 0.20 .

Recruitment for the study was conducted in a random fashion using a systematic technique. The invitation to participate in the experiment was carried out by giving forms numbered one to four in numerical order to women as they arrived at the health service where the study was being carried out.

After meeting the inclusion criteria, the women were randomized again and allocated to the eight study groups: daily IS during meal times (group C), daily IS between meals (group A), IS twice weekly during meal times (group F) and IS twice weekly between meals (group E). The other four groups (B, $\mathrm{D}, \mathrm{G}, \mathrm{H})$ were put on similar regimens, using the placebo instead of the IS (Figure 1).

A questionnaire was applied on recruitment to characterize the population under study, including personal data, telephone numbers, socio-demographic data, the use of medication and pre-existing conditions.

On recruitment, each participant was given a set of instructions, a labeled flask, indicating the dosage, containing enough pills for eight weeks (iron sulfate equivalent to $60 \mathrm{mg}$ of iron or placebo). At this stage a blood sample was obtained to determine the concentration of hemoglobin before the start of the experiment. Neither the women nor the inter- 


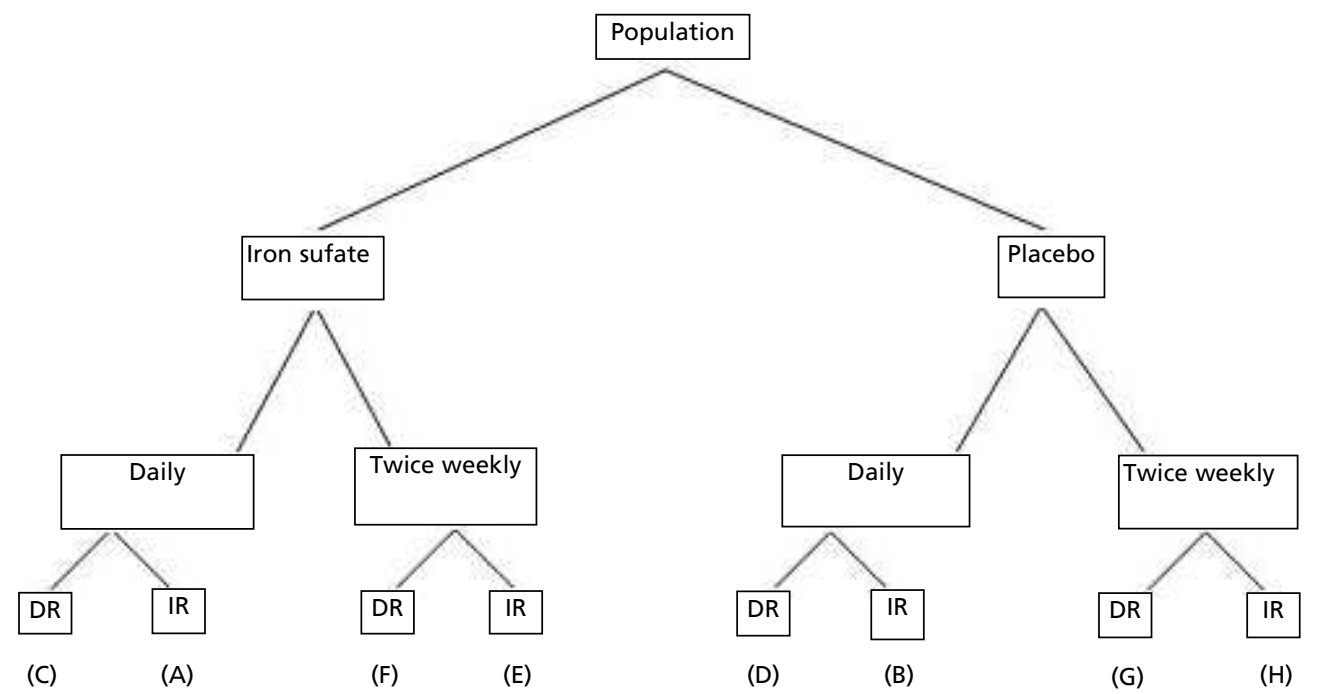

Plan for random allocation of women of reproductive age into eight study groups, by use of iron sulfate or placebo, frequency of use (daily or twice weekly) and time of administration (during - DR or in between - IR mealtimes).

viewers were aware which women had been allocated to the placebo and which to the iron sulfate group.

Another questionnaire was applied by telephone every seven days, in order to confirm that the women had taken the correct dose and to register any complaints or reasons for abandoning the study. The researchers who conducted the telephone interviews did not know which women were taking iron sulfate and which the placebo.

The variables relating to side-effects attributed to the use of the medication were nausea, loss of appetite, colic, itching, vomiting, epigastric pain, diarrhea, headaches, a metallic taste, general malaise, intestinal constipation, loss of appetite and dizziness.

The statistical analysis was carried out using Epi Info 6.04 and STATA. Pearson's chi-squared test was used to compare the proportions from the groups registering complaints: use of iron sulfate versus use of placebo; use of iron sulfate daily versus weekly; use of iron sulfate during meal times versus between meals, and frequency of and reasons for abandoning treatment for the different doses in the iron sulfate and the placebo groups. For all tests the level of significance was set at 5\%.

All the participants were informed of the aims of the research and signed Terms of Free Informed
Consent before commencing the study. The study was approved by the Universidade de Pernambuco (UPE) Research Ethics Committee.

\section{Results}

Of the 727 women who began the experiment, 95 left because of side-effects: constipation, diarrhea and nausea (Table 1), seven for other reasons and 86 during follow up, giving a total of 188 losses $(25.8 \%)$. Comparison of the age and level of education of the losses with the remaining group $(n=539)$ showed that there were no statistically significant differences ( $p>0.05$ for both variables).

4661 telephone calls were made during the eight weeks of follow-up, of which $2221(47.7 \%)$ were to the IS group and $2440(52.3 \%)$ to the placebo group. It was recorded that $10.8 \%(504 / 4661)$ reported complaints during the telephone conversations, of which $10.2 \%(\mathrm{n}=480)$ were in the IS group and $0.6 \%$ $(\mathrm{n}=24)$ in the placebo group $(p<0,001)$, malaise and diarrhea being the most commonly reported sideeffects. $(p<0.001$; Table 2$)$.

Investigation of the 480 complaints in the weekly and daily IS groups found that $78.7 \%$ of these occurred among those in the daily group $(p<0.001)$. All complaints were more frequent in the daily IS group and this difference was the greatest in 
the case of constipation (Table 3 ).

No difference was observed in the frequency of complaints when comparing the use of IS during (DR) or between (IR) meals, with the exception of complaints of diarrhea (which were more common with DR) and nausea (which was more common in the IR group). (Table 4).
Of the subgroup of 95 women who abandoned the experiment complaining of side-effects $88.4 \%$ belonged to the groups using IS. The groups who used IS daily between and during meals contained the most women who abandoned the experiment compared to the groups taking the placebo according to the same regimen $(p<0,001$; Table 5$)$.

Table 1

Reasons for abandoning the experiment given by 95 women in the iron sulfate and placebo groups. Recife, 2006.

\begin{tabular}{|c|c|c|c|c|c|c|}
\hline \multirow[t]{2}{*}{ Reasons } & \multicolumn{2}{|c|}{ Iron sulfate } & \multicolumn{2}{|c|}{ Placebo } & \multicolumn{2}{|c|}{ Total } \\
\hline & $\mathrm{n}$ & $\%$ & $\mathrm{n}$ & $\%$ & $\mathrm{n}$ & $\%$ \\
\hline Constipation & 20 & 100.0 & - & - & 20 & 21.0 \\
\hline Diarrhea & 25 & 96.2 & 1 & 3.8 & 26 & 27.4 \\
\hline Nauseas & 22 & 95.6 & 1 & 4.3 & 23 & 24.2 \\
\hline Headaches & 16 & 69.6 & 7 & 30.4 & 23 & 24.2 \\
\hline Weight gain & 1 & 33.3 & 2 & 66.7 & 3 & 3.2 \\
\hline Total & 84 & 88.4 & 11 & 11.6 & 95 & 100.0 \\
\hline
\end{tabular}

Table 2

Distribution of complaints reported in the groups that used iron sulfate and placebo during the 4656 telephone conversations. Recife, 2005-2006.

\begin{tabular}{|c|c|c|c|c|c|c|c|}
\hline \multirow[t]{2}{*}{ Complaints } & \multicolumn{2}{|c|}{ Iron sulfate } & \multicolumn{2}{|c|}{ Placebo } & \multicolumn{2}{|c|}{ Total } & \multirow[t]{2}{*}{$p^{*}$} \\
\hline & $\mathrm{n}$ & $\%$ & $\mathrm{n}$ & $\%$ & $\mathrm{n}$ & $\%$ & \\
\hline Malaise & 94 & 93.1 & 7 & 6.9 & 101 & 20.0 & $<0.001$ \\
\hline Diarrhea & 97 & 97.0 & 3 & 3.0 & 100 & 20.0 & $<0.001$ \\
\hline Nausea & 78 & 90.7 & 8 & 9.3 & 86 & 17.0 & $<0.001$ \\
\hline Constipation & 76 & 97.4 & 2 & 2.6 & 78 & 15.5 & $<0.001$ \\
\hline Intestinal colic & 70 & 98.6 & 1 & 1.4 & 71 & 14.0 & $<0.001$ \\
\hline Epigastric pain & 33 & 94.3 & 2 & 5.7 & 35 & 7.0 & $<0.001$ \\
\hline Metallic taste & 32 & 97.0 & 1 & 3.0 & 33 & 6.5 & $<0.001$ \\
\hline Total & 480 & 95.2 & 24 & 4.8 & 504 & 100.0 & $<0.001$ \\
\hline
\end{tabular}

*Pearson's chi-square test.

Table 3

Distribution of complaints in the groups taking iron sulfate, daily and twice weekly during the 2218 telephone conversations. Recife, 2005-2006.

\begin{tabular}{|c|c|c|c|c|c|c|c|}
\hline \multirow[t]{2}{*}{ Complaints } & \multicolumn{2}{|c|}{ Daily } & \multicolumn{2}{|c|}{ Twice weekly } & \multicolumn{2}{|c|}{ Total } & \multirow[t]{2}{*}{$p^{*}$} \\
\hline & $\mathrm{n}$ & $\%$ & $\mathrm{n}$ & $\%$ & $\mathrm{n}$ & $\%$ & \\
\hline Malaise & 66 & 68.0 & 31 & 32.0 & 97 & 20.2 & $<0.001$ \\
\hline Diarrhea & 78 & 83.0 & 16 & 17.0 & 94 & 19.6 & $<0.001$ \\
\hline Nausea & 66 & 84.6 & 12 & 15.4 & 78 & 16.2 & $<0.001$ \\
\hline Constipation & 71 & 93.4 & 5 & 6.6 & 76 & 15.8 & $<0.001$ \\
\hline Intestinal colic & 48 & 68.6 & 22 & 31.4 & 70 & 14.6 & $<0.001$ \\
\hline Epigastric pain & 20 & 60.6 & 13 & 39.4 & 33 & 6.9 & $<0.001$ \\
\hline Metallic taste & 29 & 90.6 & 3 & 9.4 & 32 & 6.7 & $<0.001$ \\
\hline Total & 378 & 78.7 & 102 & 21.3 & 480 & 100.0 & $<0.001$ \\
\hline
\end{tabular}

*Pearson's chi-square test. 
Distribution of complaints in the groups taking iron sulfate, during and between mealtimes in the 2218 telephone conversations. Recife, 2005-2006.

\begin{tabular}{|c|c|c|c|c|c|c|c|}
\hline \multirow[t]{2}{*}{ Complaints } & \multicolumn{2}{|c|}{ During mealtimes } & \multicolumn{2}{|c|}{ Between meals } & \multicolumn{2}{|c|}{ Total } & \multirow[t]{2}{*}{$p^{*}$} \\
\hline & $\mathrm{n}$ & $\%$ & $\mathrm{n}$ & $\%$ & $n$ & $\%$ & \\
\hline Malaise & 59 & 60.8 & 38 & 39.2 & 97 & 20.2 & 0.040 \\
\hline Diarrhea & 41 & 43.6 & 53 & 56.4 & 94 & 19.6 & 0.164 \\
\hline Nausea & 20 & 25.6 & 58 & 74.4 & 78 & 16.2 & $<0.001$ \\
\hline Constipation & 39 & 51.3 & 37 & 48.7 & 76 & 15.8 & 0.903 \\
\hline Intestinal colic & 36 & 51.4 & 34 & 48.6 & 70 & 14.6 & 0.892 \\
\hline Epigastric pain & 17 & 51.5 & 16 & 48.5 & 33 & 6.9 & 0.918 \\
\hline Metallic taste & 20 & 62.5 & 12 & 37.5 & 32 & 6.7 & 0.176 \\
\hline Total & 232 & 48.4 & 248 & 51.6 & 480 & 100.0 & \\
\hline
\end{tabular}

*Pearson's chi-square test.

Table 5

Distribution of the 95 women who abandoned treatment complaining of side-effects by iron-sulfate or placebo group. Recife, 2005-2006.

\begin{tabular}{|c|c|c|c|c|c|}
\hline \multirow[t]{2}{*}{ Groups } & \multicolumn{2}{|c|}{ Iron sulfate } & \multicolumn{2}{|c|}{ Placebo } & \multirow[t]{2}{*}{$p^{*}$} \\
\hline & $\mathrm{n}$ & $\%$ & $\mathrm{n}$ & $\%$ & \\
\hline Daily and between meals & 34 & 94.4 & 3 & 5.6 & $<0.001$ \\
\hline Daily and during meal times & 28 & 100.0 & - & - & - \\
\hline Twice weekly and between meals & 9 & 64.3 & 5 & 35.7 & 0.266 \\
\hline Twice weekly and during meal times & 13 & 81.2 & 3 & 18.8 & 0.009 \\
\hline Total & 84 & 88.4 & 11 & 11.6 & \\
\hline
\end{tabular}

*Pearson's chi-square test.

\section{Discussion}

Studies of adherence and the side-effects of iron salts are very diverse, differing in terms of population and duration, dosage, concepts and the way adherence, abandonment of treatment and reported complaints are measured. This is one of the main difficulties for interpretation and analysis of the results reported here. ${ }^{9-11}$ On the other hand, the studies are unanimous in choosing IS as the most efficient treatment for anemia. ${ }^{1,12-15}$

A peculiarity of this study that should be taken into consideration was that fact that the follow-up was carried out by way of telephone interviews, which are rarely used for studies of adherence, 17 although there are some reports that this technique can provide results similar to those of face-to-face interviews in terms of reliability. ${ }^{18,19}$ It was striking that even though this study was conducted with a sample of low-income individuals using public health services, all the women had a telephone number at which they could be contacted. The loss of follow-up for reason of not being able to contact the women was roughly $12 \%$, suggesting that this loss did not bias the results of the experiment. ${ }^{20}$ It is important to note that the level of education of those women lost to the study did not differ from that of those who remained in it, as it has been reported that low levels of schooling may be a restriction on efforts to combat anemia. 21,22

The duration of the study of eight weeks is similar to that of most studies involving daily and weekly IS regimens, which vary from eight to 16 weeks. 12,15

The present study found that the use of IS was responsible for the gastro-intestinal complaints reported by the women, corroborating previous findings. $1,9,10,23$ Reported complaints were more frequent among those taking IS daily than among those taking it twice a week. This is in accordance with various other studies that suggest that two intermittent doses, when treating anemia, may be more 
effective in improving adherence, owing to the lower incidence of side-effects. 7,12,13,15,23

The side-effects, taken in isolation show that the most frequently reported complaints were malaise, diarrhea and constipation, especially in the groups that took IS on a daily basis. Other studies have found variations in the frequency for various different complaints relating to the gastrointestinal tract that this is probably due to the fact that studies examined such effects in different sectors of the population, ${ }^{21-23}$ although most complaints still refer predominantly to the gastrointestinal tract. The findings of this study are in accordance with the literature, where it has been noted that the presence of such gastrointestinal effects interfere with adherence to treatment for anemia.6,10-12

A study conducted among pregnant women in the same locality observed that abandonment of treatment for reason of diarrhea or epigastric pain was found only in the group that used IS on a daily

\section{References}

1. WHO (World Health Organization). Iron deficiency anemia: assessment, prevention, and control: a guide for program managers. Geneva; 2001.

2. Viteri FE. Iron supplementation for the control of iron deficiency in populations at risk. Nutr Rev. 1997; 55: 195-209.

3. Fabian C, Olinto MTA, Dias-da-Costa JS, Bairros F, Nácul LC. Prevalência de anemia e fatores associados em mulheres adultas residentes em São Leopoldo, Rio Grande do Sul, Brasil. Cad Saúde Pública. 2007; 23: 1199-205.

4. Coutinho GGPL, Goloni-Bertollo EM, Pavarino-Bertelli EC. Effectiveness of two programs of intermittent ferrous supplementation for treating iron-deficiency anemia in infants: randomized clinical trial. Sao Paulo Med J. 2008; 126: 314-8.

5. Carvalho AGC, Lira PIC, Barros MFA, Aléssio MLM, Lima MC, Carbonneau MA. Diagnosis of iron deficiency anemia in children of Northeast Brazil. Rev Saúde Pública. 2010; 44: 513-9.

6. Young MW, Lupafya E, Kapenda E, Bobrow EA. The effectiveness of weekly iron supplementation in pregnant women of rural northern Malawi. Trop Doct. 2000; 30: 848 .

7. Souza AI, Batista Filho M. Diagnóstico e tratamento das anemias carenciais na gestação: consensos e controvérsias. Rev Bras Saúde Matern Infant. 2003; 3: 473-9.

8. Ferreira MLM, Ferreira LOC, Silva AA, Batista-Filho M. Efetividade da aplicação do iron sulfate em doses semanais no Programa Saúde da Família em Caruaru, Pernambuco, Brasil. Cad Saúde Pública. 2003; 19: 375-81.

9. Haas JD, Brownlie TIV. Iron deficiency and reduced work capacity: a critical review of the research to determine a causal relationship. J Nutr. 2001; 131 (suppl. 2): 676S-90S. basis and not in those groups that took the medication twice weekly. The study further found that side effects, especially epigastric pain and diarrhea, were directly proportional to the frequency of use of iron supplements. 12

In the present study, the administration of IS led to the development of diarrhea as a side-effect, regardless of the regimen, although this was more common when the drug was taken on a daily basis. It can thus be suggested that the twice-weekly regimen, rather than the daily one, leads to greater adherence and thus lower levels of abandonment for reason of side effects, especially gastrointestinal ones, since it would appear to have been shown that iron salts administered in lower doses on a weekly basis may reduce side-effects.

Nevertheless, more in-depth studies are still needed to investigate any possible difference in sideeffects between groups who take the drug between and during mealtimes.

10. Sölvell L. Oral iron therapy: side effects. In: Halberg L, Harwerth HG, Vannoti A. Iron deficiency: pathogenesis, clinical aspects, therapy. London: Academic Press; 1970. p. 573-83.

11. Olivares GM. Iron supplementation. Rev Chil Nutr. 2004; 31: 272-5.

12. Souza AI, Batista Filho M, Ferreira LOC, Figuerôa JN. Efetividade de três esquemas com iron sulfate para tratamento de anemia em gestantes. Rev Panam Salud Publica. 2004; 15: 313-9.

13. Hyder SMZ, Persson LA, Ekström EC. Do side-effects reduce compliance to iron supplementation? A study of daily-and weekly-dose regimens in pregnancy. J Health Popul Nutr. 2002; 20: 175-9.

14. Ashmead HD. The absorption and metabolism of iron amino acid chelate. Arch Latinoam Nutr. 2001; 51 (Suppl. 1): $13-21$.

15. Lopes MCS, Ferreira LO, Batista Filho M. Uso diário e semanal de iron sulfate no tratamento da anemia em mulheres no período reprodutivo. Cad Saúde Pública. 1999; 15: 799-808.

16. Kirkwood BR. Essentiais of medical statistics. London: Blackwell Sientific Publications; 1998. Chapter 26. Calculation of required sample size. 196p.

17. Leite SN, Vasconcellos MPC. Adesão à terapêutica medicamentosa: elementos para a discussão de conceitos e pressupostos adotados na literatura. Ciênc Saúde Coletiva. 2003; 8: 775-82.

18. Lima FEL, Slater B, Latorre MRDO, Fisberg RM. Validade de um questionário quantitativo de frequência alimentar desenvolvido para população feminina no nordeste do Brasil. Rev Bras Epidemiol. 2007; 10: 483-90. 
19. Monteiro CA, Erly CM, Patrícia CJ, Alessandra L, Alex AF, Iramaia CRF, Regina B, Nilza NS. Monitoramento de fatores de risco para doenças crônicas por entrevistas telefônicas. Rev Saúde Pública. 2005; 39: 47-57.

20. Hennekens CH, Buring JE. Epidemiology in medicine. Boston: Litle Brown and Company; 1987. 383 p

21. Vitolo MR, Boscaini C, Bortolini, GA. Baixa escolaridade como fator limitante para o combate à anemia entre gestantes. Rev Bras Ginecol Obstet. 2006; 28: 331-9.
22. Dairo MD, Lawoyin TO. Demographic factors determining compliance to iron supplementation in pregnancy in Oyo State, Nigeria. Niger J Med. 2006; 15: 241-4.

23. Souza AI, Batista-Filho M, Bresani CC, Ferreira LOC, Figueiroa JN. Adherence and side effects of three ferrous sulfate treatment regimens on anemic pregnant women in clinical trials. Cad Saúde Pública. 2009; 25: 1225-33.

Recebido em 3 de janeiro de 2011

Versão final apresentada em 7 de julho de 2011

Aprovado em 1 de agosto de 2011 